\title{
THE EFFECTIVENESS OF REFLECTIVE-INTUITIVE AL FATIHAH READING THERAPY IN REDUCING AUTOIMMUNE SURVIVOR STRESS
}

\author{
Muhammad Fauzan Elka Putra \\ Universitas Islam Indonesia (UII) Yogyakarta, elkaputrafauzan@gmail.com
}

Fuad Nashori

Universitas Islam Indonesia (UII) Yogyakarta, fuadnashori@uii.ac.id

\author{
(c) (1) (-) \\ C 2021 by the authors. Submitted for possible open access publication under the terms and conditions \\ of the Creative Commons Attribution-ShareAlike 4.0 International License (CC-BY-SA) \\ license (https://creativecommons.org/licenses/by-sa/4.0/) \\ doi) DOI: http://dx.doi.org/10.30983/fuaduna.v5i1.4218 \\ \begin{tabular}{l|l|r} 
Submission: 27 February 2021 & Revised: 18 June 2021 & Published: 30 June 2021
\end{tabular}
}

\begin{abstract}
This study aims to investigate the employment of a reflective-intuitive reading of the $\mathrm{Al}$ Fatihah chapter as a therapy to decrease stress levels in patients with autoimmune. Conducting experimental research, the research design of this study is a non-randomized pretest-posttest control group and the participant recruited are female Muslims suffering from one of the autoimmune diseases. In this research, to measure stress levels, this study adapts a stress subtest of the Depression Anxiety Stress Scale (DASS) in which the Indonesian language is used to administer the scale. The therapy itself adopts Maulana, Subandi, and Asturi's (2016) module of a reflective-intuitive reading of the Al Fatihah chapter. The data are analyzed through the Mann-Whitney U-Test in order to figure out the differences of the levels of stress in the experimental group before and after the intervention given and afterward to compare it to the control group. This study reveals the meaning process in the reflective-intuitive reading of the Al Fatihah for a particular time could decrease the levels of stress of patients with an autoimmune disease.
\end{abstract}

Keywords: Immune System; Autoimmune Survivor; Therapy.

\begin{abstract}
Abstrak
Penelitian ini bertujuan untuk mengkaji peran terapi membaca Al Fatibah reflektifintuitif dalam penurunan tingkat stres pada pasien autoimun. Penelitian ini menggunakan metode eksperimen kuasi dengan desain non-randomized pretest-posttest control group design. Subjek yang dilibatkan dalam penelitian ini adalah perempuan yang beragama Islam dan menderita salab satu penyakit autoimun. Dalam penelitian ini tingkat stres subjek diukur menggunakan Depression Anxiety Stress Scale (DASS) subtes stres yang sudah diadaptasi ke dalam bahasa Indonesia. Pelaksanaan terapi mengacu pada modul membaca Al Fatibah reflektif-intuitif yang dikembangkan peneliti dan tim dengan merujuk pada modul Maulana, Subandi, dan Asturi. Analisis data menggunakan uji Mann Whitney U-Test untuk mengetahui perbedaan tingkat stres pada kelompok perlakuan di saat sebelum dan sesudah intervensi dibandingkan dengan kelompok kontrol. Hasil penelitian menunjukean babwa terapi membaca Al Fatibah reflektif-intuitif dapat menurunkan tingkat stres pada pasien autoimun setelah melewati proses pemaknaan yang menghabiskan waktu tertentu.
\end{abstract}

Kata Kunci: Sistem Imun; Penyintas Autoimun; Terapi. 


\section{INTRODUCTION}

Autoimmune disease is an immune disorder characterized by tissue damage. The immune system of a person with an autoimmune disease mistakenly identifies a foreign object, thus damaging the individual's cells or tissues. ${ }^{1}$ This causes autoimmune diseases do not increase in the body's strength to fight the existing disease. However, on the contrary, this situation causes tissue or organ damage due to the immune system attacking the individual's body.

Two theories can explain the process of the emergence of autoimmune diseases in individuals. $^{2}$ The first theory explains that immune disorders can arise because there are errors in lymphocyte DNA deletions to identify self-antigens. The next theory explains the emergence of immune disorders because there is a failure to regulate the immune system in which antigens are suppressed. As for some examples of diseases that arise due to impaired immunity are: Rheumatoid Arthritis (RA), Systemic Lupus Erythematosus (SLE), Antiphospholipid Syndrome (AS).

Autoimmune disease is one of the chronic diseases that has received less attention than other chronic diseases such as cancer, AIDS, and heart disease. Existing data show that autoimmune disease is one of the most common health problems, one of which is in Indonesia. Data shows that in Indonesia in 2017 as much as $0.5 \%$ or around $1,250 / 000$ Indonesian population suffer from autoimmune diseases such as Rheumatoid Arthritis (RA), Systemic Lupus Erythematosus (SLE), Antiphospholipid Syndrom (AS) which attacks individuals aged 15-44 years which primarily attacks women. RA disease, commonly called rheumatism, is a chronic systemic disorder that attacks organ tissues, especially flexible

1 Endang Purwaningsih, "Disfungsi Telomer Pada Penyakit Autoimun,” Jurnal Kedokteran YARSI 21 (2013): 41-49.

2 Karnen G Baratawidjaja and I Rengganis, "Imunologi Dasar Edisi Ke Sepuluh," Jakarta: Balai Penerbit FKUI, 2012. joints, has a prevalence of $0.1 \%$ to $0.3 \%$ in adults and then 1:100 thousand are children. ${ }^{3}$

Furthermore, lupus is an idiopathic chronic inflammatory disease accompanied by complex clinical manifestations and can cause death. ${ }^{4}$ This disease has a prevalence of about 5 100 per 100,000 individuals with a five to ten times greater chance of occurring in women. ${ }^{5}$ Autoimmune disease conditions in hospitals are increasing every year. As in 2014-2016 in Indonesia there were 1,169 cases and the number of deaths due to autoimmune diseases which also increased dramatically to 550 deaths. ${ }^{6}$

The significant impact of autoimmune diseases on sufferers is experiencing excessive pain, prone to health problems, such as a high risk of developing kidney disease, heart disease, and osteoporosis. ${ }^{7}$ Variables that affect the physical and mental health of people with autoimmune diseases are depression, anxiety, and stress. ${ }^{8}$ In reality, people with autoimmune diseases must face conditions of physical limitations that can hinder their daily activities. This can be a particular stressor for people with autoimmune diseases.

People with autoimmune diseases will face physical stressors and psychological

${ }^{3}$ Info Datin, Situasi Lupus Di Indonesia (Kementrian Kesehatan RI, 2017), https://pusdatin.kemkes.go.id/article/view/17072400003/ situasi-penyakit-lupus-di-indonesia.html.

4 J. Michelle Kahlenberg and Mariana J. Kaplan, "The Interplay of Inflammation and Cardiovascular Disease in Systemic Lupus Erythematosus," Arthritis Research and Therapy 13 (2011): 1-10.

${ }^{5}$ Info Datin, Situasi Lupus Di Indonesia, 3.

${ }^{6}$ Ibid, 15.

7 Elvira Sari Dewi, Soemardini Soemardini, and Ika Setyo Rini, "Efektivitas Terapi Kompres Dingin Dalam Menurunkan Stres Orang Dengan Lupus (Odapus) Dewasa Muda Di Perhimpunan Masyarakat Peduli Lupus Parahita Malang," Majalah Kesehatan FKUB 3 (2016): 65-75, https://majalahfk.ub.ac.id/index.php/mkfkub/article/view 192 .

8 N. Navarrete-Navarrete et al., "Quality-of-Life Predictor Factors in Patients with SLE and Their Modification after Cognitive Behavioural Therapy," Lupus 19 (December 2010): 1632-39. 
stressors. ' Physical stressors experienced by individuals with autoimmune disease are prone to fatigue, stress easily, cannot be exposed to more sunlight, and physical conditions that go up and down. While the psychological stressors experienced by individuals with autoimmune disease are a long process of diagnosis, facts that must be accepted after being diagnosed, worries about the future, and feelings of not being able to control life. This can cause tension or stress that is continuous and prolonged. Continuous and prolonged stress can harm the condition of person with autoimmune diseases. Stress can cause relapse and can also worsen the condition of the disease. ${ }^{10}$

The results of initial interviews conducted by researchers showed that patients suffering from autoimmune diseases experienced stress. S is a 37-year-old woman who suffers from SLE. S is married and has two daughters. S said she felt shocked and appeared much fear after being diagnosed with autoimmune disease by the doctor. One of S's biggest fears is the fear that no one will take care of his two children and her children will be neglected. S's husband works out of town so S lives at home with his two children. Currently, S's physical condition has undergone various changes, such as a pale face, dry and cracked palms, and black and bloody lips. S explained further that her current condition is very dependent on her psychological state. S explained that her body would respond to pain in certain parts when feeling sad or angry. S feels bored with her current condition which has to undergo a tiring treatment process and has to take a lot of drugs at one time. This often makes it difficult for $\mathrm{S}$ to control her emotions when she

${ }^{9}$ Elvira Sari Dewi, Soemardini, and Ika Setyo Rini, "Effectiveness of Cold Compress Therapy to Decrease Stress in Lupus Patient (Odapus) at Lupus Care Community Parahita Malang," Majalah Kesehatan FKUB 3 (2016): 1-9.

10 Laura Plantinga et al., "Perceived Stress and Reported Cognitive Symptoms among Georgia Patients with Systemic Lupus Erythematosus," Lupus 26 (2017): 1064-71. feels that the environment around him does not understand him. ${ }^{11}$

Stress is defined as a form of reciprocal influence between the individual and the environment, where the individual perceives it as a burdensome and beyond the individual's ability to demand. ${ }^{12}$ Then Sarafino explained that stress is a condition when an individual perceives a gap between the demands and the resources owned by the individual. Furthermore, Beck and Judith explain that stress can negatively impact when individuals perceive themselves as unable to cope with the pressure experienced so that it can affect the way they think and behave. ${ }^{13}$

Previous research has shown that there are several ways to reduce stress levels. Ayu, Prabowo, and Setyorini use breathing relaxation techniques to reduce stress levels. ${ }^{14}$ The study found that breathing relaxation can reduce stress levels. Then Dewi in her research showed that music therapy could increase feelings of relaxation in stressful situations to reduce stress. ${ }^{15}$ Subsequent research conducted by Hanum, Daengsari, and Kemala on the effect of implementing group stress management. ${ }^{16}$ The research question in this paper is whether $\mathrm{Al}$ Fatihah Reflection Therapy (ART) effectively reduces the stress of autoimmune survivors?

\footnotetext{
11 Sabrina (Autoimmune Patient), Interview, 2019.

12 S. Lazarus, R. S., Folkman, Stress Appraisal and Coping (New York: Springer US, 1994).

13 Amy Noerul Azmy, Achmad Juntika Nurihsan, and Eka Sakti Yudha, "Deskripsi Gejala Stres Akademik Dan Kecenderungan Pilihan Strategi Koping Siswa Berbakat," Indonesian Journal of Educational Counseling, 2017, https://doi.org/10.30653/001.201712.14.

14 Qurrotun Ayu Ayu, Sumbodo Prabowo, and Th Dewi Setyorini, "Efektivitas Terapi Relaksasi Untuk Mengurangi Tingkat Stres Kerja Bagian Penjualan PT Sinar Sosro Semarang,” PREDIKSI 2, no. 1 (2013): 58.

15 Mahargyantari P Dewi, "Studi Metaanalisis: Musik Untuk Menurunkan Stres," Jurnal Psikologi 36, no. 2 (2009): 106 - 115-115, https://doi.org/10.22146/jpsi.7889.

16 Lathifah Hanum, Dini P. Daengsari, and Cut Nurul Kemala, "Penerapan Manajemen Stres Berkelompok Dalam Menurunkan Stres Pada Lanjut Usia Berpenyakit Kronis," Jurnal Psikologi 43, no. 1 (2016): 42, https://doi.org/10.22146/jpsi.11501.
} 
If we look closely, previous research, as already explained, only focuses on the psychological aspect. This research offers a more holistic approach. There are four holistic dimensions in the individual, namely organobiological, psychoeducational, socio-cultural, and spiritual. ${ }^{17}$ Furthermore, Witmer and Sweeny suggested that the spiritual element contained in the individual combines and integrates other elements such as physical needs, emotional and intellectual needs for individual growth and development. ${ }^{18}$ Based on the description above, spiritual and religious elements are essential elements in handling mental health problems in patients with autoimmune diseases, especially in dealing with stress.

Many studies use a religious approach to reduce stress levels and have been shown to reduce stress levels in individuals. Safitri, Nashori, and Sulistyarini ${ }^{19}$ shows that remembrance relaxation is effective in reducing stress in patients with type II diabetes mellitus. In addition, some studies show that reading the Qur'an can reduce stress levels in individuals. ${ }^{20}$ Reading the Qur'an can bring up a sense of surrender to God which can later lead to favorable conditions for the body. ${ }^{21}$ The emphasis on each spoken phrase will activate the parasympathetic nerves which will decrease the body's response and bring about calm. Furthermore, remembrance relaxation therapy

17 Widuri Nur Anggraieni and Subandi Subandi, "Pengaruh Terapi Relaksasi Zikir Untuk Menurunkan Stres Pada Penderita Hipertensi Esensial," Jurnal Intervensi Psikologi (JIP) 6, no. 1 (2014): 81-102, https://doi.org/10.20885/intervensipsikologi.vol6.iss1.art6.

18 Anggraieni and Subandi.

19 Saulia Safitri, H Fuad Nashori, and Indahria Sulistyarini, "Relaxation With Dhikr To Decrease Stress Among Type II Diabetes Patients," Jurnal Intervensi Psikologi 9, no. 1 (2017): 1-15.

20 Dian Nugraheni, Moh Iqbal Mabruri, and Sugiyarta Stanislaus, "Efektivitas Membaca Al-Qur'an Untuk Menurunkan Stres Akademik Pada Siswa Kelas Xi SMA Negeri 1 Kebumen," Intuisi: Jurnal Psikologi Ilmiah 10, no. 1 (2018): 59-71.

21 Saktiyono B Purwoko, "Terapi Refleksi AlFatihah (Al-Fatihah Reflection Therapy)," Psikologika: Jurnal Pemikiran Dan Penelitian Psikologi 18, no. 2 (2013): 129-41. also has a significant effect on reducing individual stress levels. ${ }^{22}$ This is because remembrance has a relaxing power that can reduce stress and bring peace of mind. Dhikr that is done with full appreciation will make the individual in a calm and comfortable state. This is because every word in remembrance can be a point of attention in the self-healing process from physical and psychological complaints.

In addition, there is Al Fatibah Reflection Therapy (ART) which can reduce individual stress levels. ART, commonly known as Al Fatihah reflection therapy, has been proven to reduce stress levels in individuals effectively. ${ }^{23}$ Elkadi explained the effect of the sound produced when reading $\mathrm{Al}$ Fatihah and the meaning of reading $\mathrm{Al}$ Fatihah being able to change the individual's dysfunctional feelings without going through the cognitive process. $^{24}$ In addition, ART has advantages, namely having a vertical (theistic) dimension through the $\mathrm{Al}$ Fatihah verse to reflect dysfunctional thoughts, feelings, and behaviors. ${ }^{25}$ Then the development of the ART module led to a reflective-intuitive $\mathrm{Al}$ Fatihah reading intervention module. In his research, reflectiveintuitive $\mathrm{Al}$ Fatihah reading therapy can reduce depression as measured using the DASS scale and increase immunity, which is measured using a tool called hematology analyzer. ${ }^{26}$

Reflective-intuitive Al Fatihah reading therapy involves interpreting the contents of each of the verses of Surah Al Fatihah which is one of the processes in tąkiyatun nafs that creates a sense of calm for individuals who read Al Fatihah verses. The feeling of calm that arises due to the meaning of the Al Fatihah verse will cause a

22 Anggraieni and Subandi, "Pengaruh Terapi Relaksasi Zikir Untuk Menurunkan Stres Pada Penderita Hipertensi Esensial," 83.

23 Purwoko, "Terapi Refleksi Al-Fatihah (Al-Fatihah Reflection Therapy)," 127.

${ }^{24}$ Ibid, 129.

25 Ibid, 133.

26 Very Julianto and Subandi, "Membaca Al Fatihah Reflektif Intuitif Untuk Menurunkan Depresi Dan Meningkatkan Imunitas," Jurnal Psikologi 42, no. 1 (2015): 34, https://doi.org/10.22146/jpsi.6941. 
decrease in stress levels in individuals. Not only that, the study also explained that reading $\mathrm{Al}$ Fatihah reflectively-intuitively was able to change individual perceptions in viewing the problems experienced. ${ }^{27}$ Furthermore, the output of reading reflective-intuitive $\mathrm{Al}$ Fatihah is able to have a positive influence.

Al Fatihah reading therapy that is carried out involves a reflective process and an intuitive process. $^{28}$ The reflective process is by understanding in depth the entire verse of $\mathrm{Al}$ Fatihah. Individuals are invited to read Al Fatihah in tartil and then understand the entire verse that is read. Then proceed with the intuitive process, which is to live and feel the meaning in the $\mathrm{Al}$ Fatihah verses one by one which the facilitator guides. The reflective process and intuitive process in reading the Al Fatihah verse create a firm grip on the individual's life (anchor) to God so that later the individual can return all things that happen to Allah's provisions.

In implementing therapy, the individual is first introduced to etiquette in reading $\mathrm{Al}$ Fatihah, such as giving up on reading $\mathrm{Al} \mathrm{Fatihah,} \mathrm{then}$ proceeding with reading istigfar and tawadhu (humility before Allah) reading prayer before starting to read $\mathrm{Al}$ Fatihah. After that, the individual is introduced to the reflective-intuitive Al Fatihah reading technique. That is understanding and reflecting on each $\mathrm{Al}$ Fatihah verse that is read and then being guided by the facilitator to appreciate the meaning of each verse read. In the implementation of reading the $\mathrm{Al}$ Fatihah verse, it is conducted by making a sound that can be heard by the surrounding people and repeated three times. This activity aims to bring motivation and understanding to the reader). Then it ends by reading the khatmil Quran prayer at the end of each session.

The research conducted by this researcher uses reflective-intuitive $\mathrm{Al}$ Fatihah reading therapy in autoimmune patients by using a

${ }^{27}$ Ibid, 36.
${ }^{28}$ Ibid, 39. module developed by the author and the team that refers to the module compiled by Maulana, Subandi, and Astuti. ${ }^{29}$ Researchers use reflectiveintuitive $\mathrm{Al}$ Fatihah reading therapy because of several advantages possessed by this therapy. The first advantage is that in reflective-intuitive $\mathrm{Al}$ Fatihah reading therapy, the subject is invited to understand and reflect on the entire Al Fatihah verse and then be guided to appreciate all the verses that are read, in contrast to ART reflects on selected verses depending on individual problems. Furthermore, the advantage of reflective-intuitive $\mathrm{Al}$ Fatihah reading therapy is that it focuses on confirming the view of life (anchor) to God, so that individuals can return all events that occur to God's provisions. Whereas ART focuses on changing dysfunctional thoughts, feelings and behaviors to become more adaptive through cognitive restructuring using the Al Fatihah verse.

This study aims to determine the effectiveness of reflective-intuitive $\mathrm{Al}$ Fatihah reading therapy in reducing stress levels in patients with autoimmune diseases. Reflectiveintuitive $\mathrm{Al}$ Fatihah reading therapy is able to create a sense of calm in individuals through the process of meaning from each content of the $\mathrm{Al}$ Fatihah verse which is one of the processes in tazkiyatun nafs. Based on the explanation above, the hypothesis proposed in this study is that $\mathrm{Al}$ Fatihah reflection therapy is an effect on reducing stress levels in patients with autoimmune diseases.

The research was conducted using a quasi-experimental method with a pretest-posttest control group design experimental design. Measurements were carried out three times, namely before treatment in the form of reflectiveintuitive al Fatihah reading therapy (pre-test), immediately after treatment (first post-test), and two weeks after treatment (second post-test).

29 Subandi and Yulianti Dwi Astuti Arif Maulana, "Terapi Al Fatihah Reflektif-Intuitif Untuk Menurunkan Gejala Depresi Pada Odha"," (Universitas Islam Indonesia, 2016). 
The research process begins with screening using the Depression Anxiety Stress Scale (DASS) stress subtest to determine the stress level of each subject before participating in the therapy process. Furthermore, the subjects were divided into the control group and the treatment group randomly. After being divided into two groups, each group took the first measurement (pre-test), second (post-first test), and third (post-second test).

The treatment used in this study was reflective-intuitive $\mathrm{Al}$ Fatihah reading therapy. This therapy involves a reflective process and an intuitive process in reading the $\mathrm{Al}$ Fatihah verse which can bring up the individual's anchor of life (anchor) to God so that later the subject can return all things that happened to their provisions, Allah.

The subjects in this study were autoimmune patients. The subjects involved were 10 people with details of 5 control groups and 5 treatment groups. The subject of this research are women around 20-50 years old, Muslim, and have a stress score in the medium or high category. The female gender was chosen because, based on the Ministry of Health data, autoimmune diseases attack most women aged $15-44$ years. ${ }^{30}$ This is also done to make it easier for researchers to equalize the control and treatment groups which aims to reduce threats to the internal validity of the treatment, such as treatment and control groups being unequal due to the placement of research subjects.

The instrument used in this study to measure the pretest and posttest stress of each subject was the Depression Anxiety Stress Scale (DASS). The DASS measures stress levels based on five aspects of stress arranged in 14 items where each item has a score ranging from 0 to 3 . The DASS scale has been shown to have high validity and reliability for measuring stress, with values of 0.87 and 0.88 . This indicates that stress measurement using the DASS scale will obtain

\footnotetext{
${ }^{30}$ Info Datin, Situasi Lupus Di Indonesia.
}

valid and reliable results. The norm used to categorize the subject's stress level using the standard norm of the DASS scale.

The data analysis technique to see the difference between pretest, first posttest, and the second posttest in determining the outcome of the intervention used a non-parametric test with the Wilcoxon test. Then also use the Mann Whitney U Test to see the difference in stress levels of the treatment group compared to the control group.

\section{REDUCING AUTOIMMUNE SURVIVOR STRESS LEVEL TROUGH AL FATIHAH READING THERAPY}

At the time of pretest measurement, the treatment group had an average score of 29.40 and the control group had an average score of 23.60. In the first posttest measurement, it is known that the treatment group has an average value of 22.80 , while the control group has an average value of 26.20 . In the second posttest measurement, it is known that the treatment group has an average value of 11.80 while the control group has an average value of 29.20. The distribution of the average score of the subject can be seen as follows:

Graphic 1.

Distribution of Patient's Average Score

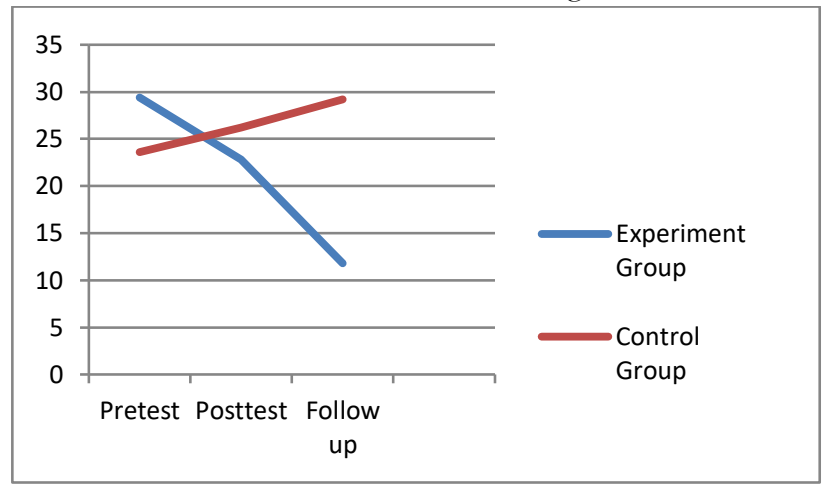

It can be seen that the control group was at a lower baseline than the treatment group and then increased in the first and second posttest measurements. Here the data show that the control group is not well isolated. Then the treatment group was at a higher baseline than the 
control group and then decreased in the first posttest and second posttest measurements.

\begin{tabular}{lcc}
\multicolumn{3}{c}{ Table 1. Mann Whitney Test } \\
\hline Test & Z Score & $\begin{array}{c}\text { Significance } \\
\text { Value }\end{array}$ \\
\hline Pretest & 1,156 & 0,248 \\
Posttest 1st & 0,952 & 0,341 \\
Posttest 2nd & 2,627 & 0,009 \\
\hline
\end{tabular}

Based on the different test results using the Mann-Whitney analysis method on the pretest measurement, the $\mathrm{Z}$ value was obtained at 1.156 with a significance coefficient of 0.248 ( $p>0.05$ ). This shows no significant difference in stress levels between the treatment group and the control group at the time of the pretest. In the first post-test measurement, the difference test with Mann Whitney analysis resulted in a $\mathrm{Z}$ value of 0.952 with a significance coefficient of 0.341 ( $p>0.05)$ so that in the first post-test it can be concluded that there is no significant difference in stress levels in the treatment group and the control group. Based on the different test results with the Mann-Whitney analysis in the second post-test measurement, the $Z$ value of 2.627 was obtained with a significance coefficient of 0.009 $(p<0.05)$. This shows a significant difference in stress levels between the treatment group and the control group in the second posttest measurement.

To find out the changes that occurred in the treatment group, a different test was performed using non-parametric statistics with Wilcoxon analysis. The following are the results of the different tests carried out by Wilcoxon analysis in this study:

Table 2. Wilcoxon Test Treatment Group

\begin{tabular}{lccc}
\hline \multicolumn{1}{c}{ Test } & Z Score & $\begin{array}{c}\text { Significance } \\
\text { Value }\end{array}$ & $\begin{array}{c}\text { Effect } \\
\text { Size }\end{array}$ \\
\hline $\begin{array}{l}\text { Pretest- } \\
\text { Posttest 1st }\end{array}$ & 1,753 & 0,080 & 0,614 \\
$\begin{array}{l}\text { Pretest- } \\
\text { Posttest 2nd }\end{array}$ & 2,032 & 0,042 & 0,825 \\
\hline
\end{tabular}

Based on the different test results using the Wilcoxon analysis method between the first pre-test and post-test, the $Z$ value was 1.753 with a significance coefficient of $0.080(p>0.05)$. This result shows that there is no significant difference between stress levels in the first pre-test and posttest. However, if we look at the value of the effect size value of 0.614 , it shows that the reflective-intuitive $\mathrm{Al}$ Fatihah reading therapy influences the large effect category. Then based on the difference test between the pre-test and the second post-test, the $Z$ value was 2.032 with a significance coefficient of $0.042 \quad(p<0.05)$. It shows that there is a significant difference between stress levels in the second pre-test and post-test. If we look at the value of the effect size of 0.825 , it shows that the reflective-intuitive $\mathrm{Al}$ Fatihah reading therapy influences the large effect category. Another result of this analysis shows that the reflective-intuitive reading training of $\mathrm{Al}$ Fatihah has a significant effect on stress levels.

Table 3. Wilcoxon Test Control Group

\begin{tabular}{lll}
\hline \multicolumn{1}{c}{ Test } & \multicolumn{1}{c}{ Z Score } & Significance Value \\
\hline $\begin{array}{l}\text { Pretest-Posttest } \\
\text { 1st }\end{array}$ & 0,542 & 0,588 \\
$\begin{array}{l}\text { Pretest-Posttest } \\
\text { 2nd }\end{array}$ & 2,023 & 0,043 \\
\hline
\end{tabular}

Based on the different tests using the Wilcoxon analysis method between the first pretest and post-test, the $Z$ value was 0.542 with a significance coefficient of 0.588 ( $p>0.05)$. It shows that there is no significant difference between stress levels in the first pre-test and posttest. Then the difference test between the second pre-test and post-test obtained a $\mathrm{Z}$ value of 2.023 with a significance coefficient of $0.043(\mathrm{p}<0.05)$. This shows that there is a significant difference between stress levels in the first pre-test and posttest. From the positive ranks value, it is known that all subjects experienced an increase in stress levels from the pretest value to the second posttest value with an average increase of 3 . 
This study aimed to determine the effect of reflective-intuitive $\mathrm{Al}$ Fatihah reading therapy on the stress level of patients with autoimmune. The high or low-stress level of a person or especially patients with the autoimmune disease in this study was seen from five aspects of stress: difficulty calming down, feeling restless, irritability, excessive response, and impatience. ${ }^{31}$ Based on the results of the analysis that has been carried out, it was found that there was no significant difference in the level of stress in patients with autoimmune after following therapy $p=0.341 \quad(p>0.05)$. Several things cause the therapy of reading $\mathrm{Al}$ Fatihah has no effect on reducing stress. The first is the unequal baseline scores of the treatment and control groups. In the treatment group was at a higher baseline then decreased in the subsequent measurement, and in the controlled group was at a lower baseline and then increased in the subsequent measurement. This causes in the first posttest measurement the scores of the two groups become closer and there seems to be no difference. The second thing is that the control group is not well isolated, so the score of the control group is increasing and increasing very significantly in the second posttest measurement.

It can happen because hypothesis testing is a process of using a limited amount of information as a basis for obtaining general conclusions. With limited information to conclude, there is always the possibility of getting the wrong conclusions even though the sample data is usually quite representative of the population. This can cause researchers to take wrong decisions. ${ }^{32}$

Then based on the results of the research carried out, it was found that there was a difference in stress levels in patients with

31 Peter F Lovibond and Sydney H Lovibond, "The Structure of Negative Emotional States: Comparison of the Depression Anxiety Stress Scales (DASS) with the Beck Depression and Anxiety Inventories," Behaviour Research and Therapy 33, no. 3 (1995): 335-43.

32 Enos Lolang, "Hipotesis Nol Dan Hipotesis Alternatif," Jurnal KIP 3, no. 3 (2015). autoimmune after taking reflective-intuitive $\mathrm{Al}$ Fatihah reading therapy between the second pretest and post-test measurements. The difference can be seen from the value of $p=0.009$ ( $p$ $<0.05)$. The $\mathrm{p}$ value results can be assumed that there is a significant change in the stress level of patients with autoimmune after being given reflective-intuitive $\mathrm{Al}$ Fatihah reading therapy on the second post-test measurement. This shows that reflective-intuitive al Fatihah reading therapy is effective in reducing stress after a time process. The time process allows individuals to get meaning for the therapeutic process they have undergone.

The results of this study support the theory and the results of previous studies that religiosity, in this case the reflective-intuitive reading of $\mathrm{Al}$ Fatihah, effectively reduces personal stress. In general, interventions based on the Qur'an are effective in increasing various favorable psychological conditions of individuals and reducing individual negative psychological conditions. $^{33}$ The opinions and results of the research above are specifically supported by research which shows that reading the Qur'an can lead to a sense of surrender to God which will later bring positive conditions to the individual body. ${ }^{34}$ It is also known that religious activities carried out with full appreciation will make individuals feel calm and comfortable. ${ }^{35}$ This is related to the individual experience span which consists of four holistic dimensions, namely organo-biological, psychoeducational, sociocultural and spiritual. ${ }^{36}$

${ }^{33}$ Fuad Nashori et al., "Decreasing Insomnia among College Students with Dyspepsia Gastritis: The Role of Islamic-Cognitive Behavioral Therapy," Talent Development \& Excellence 12, no. 1 (2020): 4436-51.

34 Purwoko, "Terapi Refleksi Al-Fatihah (Al-Fatihah Reflection Therapy).”

35 Tri Niswati Utami, "Tinjauan Literatur Mekanisme Zikir Terhadap Kesehatan: Respons Imunitas,” Jurnal JUMANTIK 100, no. 1 (2017).

36 Anggraieni and Subandi, "Pengaruh Terapi Relaksasi Zikir Untuk Menurunkan Stres Pada Penderita Hipertensi Esensial." 
In particular, high religiosity has an effect on reducing stress in individuals. ${ }^{37}$ Religiosity revives surrender. The emergence of a resigned attitude that causes an attitude of acceptance will reduce the tension caused by life's problems. One of the important religious behaviors is reading the Qur'an. Mabruri and Stanislaus' research shows that reading the holy Qur'an is effective in reducing stress in individuals. ${ }^{38}$ This is supported by the results of research showing that murattal Al-Qur'an is effective for reducing stress levels in individuals. $^{39}$

The activity of reading the Qur'an reflectively-intuitively is one method of reading the Qur'an that has the effect of reducing stress. It is known that the scores obtained showed that each subject experienced a decrease in stress levels when measuring the first posttest and second posttest. Two things happen after autoimmune patients follow the therapeutic activity of reading the Qur'an in a reflectiveintuitive manner. First: The presence of a sense of pleasure and calm. The interview results show that subject U believes that Allah SWT still gives many blessings and becomes more enthusiastic because she realizes that there are still many things in the subject's life that can still be improved..$^{40}$ Interviews on NR showed that she felt calmer and more surrendered to Allah. ${ }^{41}$ Then on the interview conduct with HY, there is a calm feeling every time she read $\mathrm{Al}$ Fatihah and becomes more grateful because Allah has given her many blessings. ${ }^{42}$

This is in line with the results of interviews which show that during the therapy process all subjects in the treatment group experience feelings of pleasure, feel more excited, remember to be grateful and relax because a feeling of calm arises in their hearts. ${ }^{43}$ This result is supported by the results of previous studies which explain that listening to or reading the Qur'an can have a positive effect on the mental health of the listener. ${ }^{44}$ The positive effects of reading and listening to the Qur'an last longer in providing calm and reducing stress if done continuously. ${ }^{45}$

Second: Feel the vibration physically and psychologically while reading the Qur'an. Another thing that the subject felt after attending therapy was feeling the vibration when reading $\mathrm{Al}$ Fatihah reflectively and intuitively and admitting being more solemn during prayer, especially when reading $\mathrm{Al}$ Fatihah verses. HY's subject stated that he felt a sensation of vibration every time he read Al Fatihah because she always remembered death, mistakes, and sins he had committed. ${ }^{46}$ Then on the subject of IW there is a feeling of shaking because they feel that they still make many mistakes and are afraid of the day of retribution. ${ }^{47}$ This is in line with previous research that reading and listening to the Qur'an can make the human soul calm because the verses in the
37 Anggraieni and Subandi.

38 Sugiyarta Nugraheni, Dian., Mabruri, Iqbal., Stanislaus, "Efektivitas Membaca Al-Qur??An Untuk Menurunkan Stres Akademik Pada Siswa Kelas XI Sma Negeri 1 Kebumen," Intuisi : Jurnal Psikologi Ilmiah 10, no. 1 (2018): 59-71.

39 Anisa Zahra Wijayanti Nugroho and Sri Kusrohmaniah, "Pengaruh Murattal Alquran Terhadap Tingkat Stres Mahasiswa Muslim Di Yogyakarta," Gadjah Mada Journal of Professional Psychology (GamaJPP) 5, no. 2 (2019): 108-19.

${ }^{40}$ Urfi (Subject), Interview, 12 August 2020.

41 Nani Rochyani (Subject), Interview, 12 August 2020 .
42 Hanifa Yuniarti (Subject), Interview, 12 August 2020.

43 Treatment Group (Subject), Interview, 12 August 2020.

44 Monireh Mahjoob and Alireaza Jalil Nejati, "Hosseini \& Noor Mohammad Bakhshani," n.d.

45 Farideh Hamidi, Zohreh Bagherzadeh, and Sobhan Gafarzadeh, "The Role of Islamic Education in Mental Health," Procedia-Social and Behavioral Sciences 5 (2010): 1991-96.

46 Hanifa Yuniarti (Subject), Interview, 12 August 2020.

47 Indri Wijayanti (Subject), Interview, 12 August 2020. 
Qur'an consist of prayer and gratitude that can thrill humans physically and psychologically. ${ }^{48}$

Several things that support the success of reflective-intuitive $\mathrm{Al}$ Fatihah reading therapy activities. These included cooperative subjects in participating in activities carried out from the first meeting to the third meeting. In addition, the subject also participated in full training activities starting from the initial session until the session ended at each meeting. Then the success of the reflective-intuitive $\mathrm{Al}$ Fatihah reading therapy activity was supported by the facilitator who delivered the reflective-intuitive $\mathrm{Al}$ Fatihah reading training material in a language that was easily understood by the research subject, so that the research subject had no difficulty understanding what was conveyed by the facilitator. The establishment of two-way communication between research subjects and facilitators is a distinct advantage in therapeutic activities. The establishment of two-way communication makes the subject has the opportunity to share her experiences about reading $\mathrm{Al}$ Fatihah reflectively and intuitively.

On the other hand, several things that are lacking in the research that has been done, such as the failure to isolate the control group. This can be seen from the increase in scores in the control group. Then errors in the selection of analytical techniques to answer the hypothesis. This causes the results of the analysis that have been carried out to be less representative. In addition, the short pause between meetings does not provide an opportunity for the subject to practice the material and do the homework that has been given.

\section{CONCLUSION}

Based on the results of research obtained through data analysis and discussions carried out, it can be concluded that reflective-intuitive $\mathrm{Al}$ Fatihah reading therapy significantly reduces

${ }^{48}$ Hamidi, Bagherzadeh, and Gafarzadeh, "The Role of Islamic Education in Mental Health.” stress levels in patients with autoimmune but must pass a particular time. Reflective-intuitive $\mathrm{Al}$ Fatihah reading therapy has a significant effect size to reduce stress levels in patients with autoimmune. When the first post-test measurement was carried out immediately after completion of reflective-intuitive al Fatihah reading therapy, the subject did not show a decrease in stress levels. However, when the second posttest measurement was taken, which was two weeks after therapy, the subjects showed a decrease in stress. It shows that the reflectiveintuitive al Fatihah reading therapy effectively reduces stress after a particular time, namely after the process of interpreting the therapy they are undergoing.

The therapeutic process of reading $\mathrm{Al}$ Fatihah reflectively-intuitively can be done to reduce perceived stress such as feelings of restlessness and irritability which then results in a feeling of calm in the heart and a sense of being more enthusiastic about living daily life despite experiencing autoimmune. The provision of reflective-intuitive $\mathrm{Al}$ Fatihah reading therapy raises the subject's spirit to be more solemn in worship and draw closer to Allah SWT.

Based on the evaluation of all the research that has been done, several things can be done for improvement for further research. The first thing is to control the isolation of the control group, so that the condition of the control group can be more stable during the post-test and second post-test measurements. Then the second thing is to adjust the selection of data analysis techniques that are more in line with the research design to answer the hypothesis. Then for further research, it is necessary to consider the interval between the intervention implementation meetings in order to be able to monitor homework assignments.

Furthermore, it is expected that subjects who have followed therapy can continue to apply the skills and knowledge that have been obtained during the implementation of therapy in everyday life. This is because reading Al Fatihah reflectively 
intuitively can bring up positive emotions to reduce the stress experienced.

\section{BIBLIOGRAPHY}

Anggraieni, Widuri Nur, and Subandi Subandi. "Pengaruh Terapi Relaksasi Zikir Untuk Menurunkan Stres Pada Penderita Hipertensi Esensial." Jurnal Intervensi Psikologi (JIP) $\quad 6$, no. 1 (2014): 81-102. https://doi.org/10.20885/intervensipsikolo gi.vol6.iss1.art6.

Arif Maulana, Subandi and Yulianti Dwi Astuti. "Terapi Al Fatihah Reflektif-Intuitif Untuk Menurunkan Gejala Depresi Pada Odha",." Universitas Islam Indonesia, 2016.

Ayu, Qurrotun Ayu, Sumbodo Prabowo, and Th Dewi Setyorini. "Efektivitas Terapi Relaksasi Untuk Mengurangi Tingkat Stres Kerja Bagian Penjualan PT Sinar Sosro Semarang." PREDIKSI 2, no. 1 (2013): 58.

Azmy, Amy Noerul, Achmad Juntika Nurihsan, and Eka Sakti Yudha. "Deskripsi Gejala Stres Akademik Dan Kecenderungan Pilihan Strategi Koping Siswa Berbakat." Indonesian Journal of Educational Counseling, 2017. https://doi.org/10.30653/001.201712.14.

Baratawidjaja, Karnen G, and I Rengganis. "Imunologi Dasar Edisi Ke Sepuluh." Jakarta: Balai Penerbit FKUI, 2012.

Dewi, Elvira Sari, Soemardini, and Ika Setyo Rini. "Effectiveness of Cold Compress Therapy to Decrease Stress in Lupus Patient (Odapus) at Lupus Care Community Parahita Malang." Majalah Kesehatan FKUB 3 (2016): 1-9.

Dewi, Elvira Sari, Soemardini Soemardini, and Ika Setyo Rini. "Efektivitas Terapi Kompres Dingin Dalam Menurunkan Stres Orang Dengan Lupus (Odapus) Dewasa Muda Di Perhimpunan Masyarakat Peduli Lupus Parahita Malang." Majalah Kesehatan FKUB 3 (2016): $65-75$. https://majalahfk.ub.ac.id/index.php/mkfk $\mathrm{ub} /$ article/view/92.

Dewi, Mahargyantari P. "Studi Metaanalisis: Musik Untuk Menurunkan Stres." Jurnal
Psikologi 36, no. 2 (2009): 106 - 115-115. https://doi.org/10.22146/jpsi.7889.

Hamidi, Farideh, Zohreh Bagherzadeh, and Sobhan Gafarzadeh. "The Role of Islamic Education in Mental Health." Procedia-Social and Behavioral Sciences 5 (2010): 1991-96.

Hanum, Lathifah, Dini P. Daengsari, and Cut Nurul Kemala. "Penerapan Manajemen Stres Berkelompok Dalam Menurunkan Stres Pada Lanjut Usia Berpenyakit Kronis.” Jurnal Psikologi 43, no. 1 (2016): 42. https://doi.org/10.22146/jpsi.11501.

Info Datin. Situasi Lupus Di Indonesia. Kementrian Kesehatan RI, 2017. https://pusdatin.kemkes.go.id/article/view/ 17072400003/situasi-penyakit-lupus-diindonesia.html.

Julianto, Very, and - Subandi. "Membaca Al Fatihah Reflektif Intuitif Untuk Menurunkan Depresi Dan Meningkatkan Imunitas." Jurnal Psikologi 42, no. 1 (2015): 34. https://doi.org/10.22146/jpsi.6941.

Kahlenberg, J. Michelle, and Mariana J. Kaplan. "The Interplay of Inflammation and Cardiovascular Disease in Systemic Lupus Erythematosus." Arthritis Research and Therapy 13 (2011): 1-10.

Lazarus, R. S., Folkman, S. Stress Appraisal and Coping. New York: Springer US, 1994.

Lolang, Enos. "Hipotesis Nol Dan Hipotesis Alternatif." Jurnal KIP 3, no. 3 (2015).

Lovibond, Peter F, and Sydney H Lovibond. "The Structure of Negative Emotional States: Comparison of the Depression Anxiety Stress Scales (DASS) with the Beck Depression and Anxiety Inventories." Behaviour Research and Therapy 33, no. 3 (1995): 335-43.

Mahjoob, Monireh, and Alireaza Jalil Nejati. "Hosseini \& Noor Mohammad Bakhshani," n.d.

Nashori, Fuad, Bahril Hidayat, Lukman, Ary Antony Putra, Yogi Kusprayogi, and Raden Rachmy Diana. "Decreasing Insomnia among College Students with Dyspepsia Gastritis: The Role of Islamic-Cognitive Behavioral Therapy." Talent Development \& 
Excellence 12, no. 1 (2020): 4436-51.

Navarrete-Navarrete, N., M. I. Peralta-Ramírez, J. M. Sabio, I. Martínez-Egea, A. Santos-Ruiz, and J. Jiménez-Alonso. "Quality-of-Life Predictor Factors in Patients with SLE and Their Modification after Cognitive Behavioural Therapy." Lupus 19 (December 2010): 1632-39.

Nugraheni, Dian., Mabruri, Iqbal., Stanislaus, Sugiyarta. "Efektivitas Membaca AlQur??An Untuk Menurunkan Stres Akademik Pada Siswa Kelas XI Sma Negeri 1 Kebumen." Intuisi: Jurnal Psikologi Ilmiah 10, no. 1 (2018): 59-71.

Nugraheni, Dian, Moh Iqbal Mabruri, and Sugiyarta Stanislaus. "Efektivitas Membaca Al-Qur'an Untuk Menurunkan Stres Akademik Pada Siswa Kelas Xi SMA Negeri 1 Kebumen." Intuisi: Jurnal Psikologi Ilmiah 10, no. 1 (2018): 59-71.

Nugroho, Anisa Zahra Wijayanti, and Sri Kusrohmaniah. "Pengaruh Murattal Alquran Terhadap Tingkat Stres Mahasiswa Muslim Di Yogyakarta." Gadjab Mada Journal of Professional Psychology (GamaJPP) 5, no. 2 (2019): 108-19.

Plantinga, Laura, S Sam Lim, C Barrett Bowling, and Cristina Drenkard. "Perceived Stress and Reported Cognitive Symptoms among Georgia Patients with Systemic Lupus Erythematosus.” Lupus 26 (2017): 1064-71.

Purwaningsih, Endang. "Disfungsi Telomer Pada Penyakit Autoimun." Jurnal Kedokteran YARSI 21 (2013): 41-49.

Purwoko, Saktiyono B. "Terapi Refleksi AlFatihah." Psikologika 18, no. 2 (2013): 129_ 41.

Purwoko, Saktiyono B. "Terapi Refleksi AlFatihah (Al-Fatihah Reflection Therapy)." Psikologika: Jurnal Pemikiran Dan Penelitian Psikologi 18, no. 2 (2013): 129-41.

Safitri, Saulia, H Fuad Nashori, and Indahria Sulistyarini. "Relaxation With Dhikr To Decrease Stress Among Type II Diabetes Patients." Jurnal Intervensi Psikologi 9, no. 1 (2017): 1-15.

Utami, Tri Niswati. "Tinjauan Literatur
Mekanisme Zikir Terhadap Kesehatan: Respons Imunitas." Jurnal JUMANTIK 100, no. 1 (2017).

\section{Interviews}

Sabrina (Autoimmune Patient), Interview, 2019.

Urfi (Subject), Interview, 12 August 2020.

Nani Rochyani (Subject), Interview, 12 August 2020.

Hanifa Yuniarti (Subject), Interview, 12 August 2020.

Kelompok Perlakuan (Subject), Interview, 12 August 2020.

Indri Wijayanti (Subject), Interview, 12 August 2020.

Treatment Group (Subject), Interview, 12 August 2020. 